\title{
KOMPOSISI JENIS KEONG POTAMIDIDAE DI EKOSISTEM MANGROVE KAWASAN PERTAMBAKAN PROBOLINGGO JAWA TIMUR
}

\author{
Ucu Yanu Arbi ${ }^{1}$, Hendriks Alexander William Cappenberg ${ }^{1}$, Yaya \\ Ihya Ulumuddin ${ }^{1}$, Mujizat Kawaroe ${ }^{2}$, Ristiyanti Marsetyowati \\ Marwoto $^{3}$ \\ ${ }^{1}$ Pusat Penelitian Oseanografi, Lembaga IImu Pengetahuan Indonesia, \\ Jakarta Utara, Indonesia \\ ${ }^{2}$ Departemen IImu Kelautan, FPIK Institut Pertanian Bogor, Bogor, \\ Indonesia \\ ${ }^{3}$ Museum Zoologi Bogor, Pusat Penelitian Biologi Lembaga IImu \\ Pengetahuan Indonesia, Cibinong, Indonesia \\ E-mail: uyanua@gmail.com
}

Received May 2019, Accepted September 2019

\begin{abstract}
ABSTRAK
Terletak di sekitar Selat Madura, Kabupaten dan Kota Probolinggo merupakan habitat dari vegetasi mangrove, tetapi keberadaan hutan mangrove di lokasi ini sebagian besar telah dikonversi menjadi areal pertambakan. Vegetasi mangrove yang tersisa tumbuh hanya di pematang tambak dan di sekitar bagian pantai. Potamididae merupakan satu-satunya famili dari gastropoda dimana semua anggotanya hanya dapat ditemukan berasosiasi dengan vegetasi mangrove. Tujuan dari penelitian ini adalah untuk mengetahui komposisi spesies keong Potamididae di areal pertambakan Probolinggo. Penelitian dilakukan pada bulan Februari dan April 2013 menggunakan metode Purposive Random Sampling di tujuh stasiun penelitian. Identifikasi spesies keong Potamididae dilakukan terutama berdasarkan karakter morfologi cangkang. Hasil penelitian menunjukkan bahwa delapan spesies keong Famili Potamididae ditemukan pada lokasi ini. Keberadaan vegetasi mangrove, jarak terdekat dengan garis pantai, suhu, salinitas dan pola arus serta pasang surut air laut dicatat sebagai faktor pendukung pertumbuhan dan perkembangan keong di lokasi penelitian. Hasil dari penelitian ini diharapkan dapat membuka peluang penelitian selanjutnya untuk mengetahui peran dan pengaruh keong Potamididae bagi kesehatan ekosistem habitat mangrove di area pertambakan.
\end{abstract}

Kata Kunci : Komposisi Spesies, Keong Potamididae, Ekosistem Mangrove, Area Pertambakan, Probolinggo 


\title{
ABSTRACT
}

\begin{abstract}
COMPOSITION OF POTAMIDID SNAILS IN THE MANGROVE ECOSYSTEM OF PROBOLINGGO POND AREA, EAST JAVA. Located around Madura Strait, Probolinggo City and Regency is a home for mangrove vegetation, but the mangrove forest in this are mostly has been converted into aquaculture ponds. The mangrove relic grows in the pond embankment and the narrow strip along the seaside. Potamididae is the only family of gastropods in which all members can only found associated with mangrove vegetation. The aim of this research was to determine species composition of potamidid snails in the pond environment of Probolinggo. The research was conducted in February and April 2013 using Purposive Random Sampling method in seven sampling stations. The species identification of the snails was based primarily on morphological shell characters. The results showed that eight species of Family Potamididae were found at the sites. The presence of mangrove trees, the distance to nearest coastline, temperature, salinity, and the pattern of ocean current and tide seemed to support the snails to grow and thrive in the study sites. The results of this study are expected to open up opportunities for further research to determine the role and influence of potamidid snails on the ecosystem health of mangrove habitat in the pond environment.
\end{abstract}

Keywords : Species Composition, Potamidid Snails, Mangrove Ecosystem, Ponds Area, Probolinggo

\section{PENDAHULUAN}

Ekosistem memiliki fungsi yang sangat penting bagi berbagai biota laut (Nagelkerken et al., 2008). Ekosistem mangrove tersebar hampir di seluruh wilayah Indonesia, namun sebagian besar telah mengalami degradasi (Sukardjo, 2009). Ancaman terutama karena adanya pengembangan untuk tujuan pembangunan infrastruktur, pertanian, tambak, urbanisasi, dan perindustrian. Setiap perubahan ekosistem mangrove akan merubah fungsi habitat biota yang berasosiasi di dalamnya, termasuk Gastropoda. Potamididae merupakan kelompok keong dalam Kelas Gastropoda yang khas untuk ekosistem mangrove, dimana semua anggotanya hanya dapat ditemukan di sekitar ekosistem mangrove (Egonmwan, 2008). Tingginya tingkat ketergantungan tersebut menjadikan keong Potamididae potensial sebagai indikator status mangrove (Reid et. al., 2008). Jenis-jenis dari famili ini ditemukan di hutan mangrove, di bekas hutan mangrove, maupun di suatu area yang terdapat tegakan mangrove sebagai tempat mencari makan, tempat perlindungan, serta tempat pemijahan dan pembesaran anakan (Wells \& Lalli, 2003).

Probolinggo merupakan salah satu wilayah di Jawa Timur yang memiliki areal mangrove. Namun demikian sebagian besar areal mangrove di wilayah ini telah dikonversi menjadi kawasan pertambakan. Perubahan fungsi lahan tersebut memungkinkan adanya perubahan 
komposisi biota yang berasosiasi di dalamnya. Informasi tentang komposisi biota yang berasosiasi dengan mangrove di wilayah ini belum banyak dilaporkan, terutama komposisi jenis moluska. Oleh karena itu, penelitian yang bertujuan untuk mengungkapkan komposisi jenis biota yang berasosiasi dengan mangrove menjadi penting untuk dilakukan. Sehingga tujuan penelitian ini adalah untuk mengetahui jenis-jenis keong Famili Potamididae di kawasan pertambakan Probolinggo, Jawa Timur.

\section{MATERI DAN METODE}

\section{Waktu dan Lokasi Penelitian}

Penelitian lapangan dilakukan pada bulan Februari dan April 2013 di areal pertambakan Kabupaten dan Kota Probolinggo, Jawa Timur. Lokasi penelitian dibagi menjadi tujuh stasiun sampling dan mencakup seluruh wilayah Kabupaten dan Kota Probolinggo (Gambar 1). Penentuan stasiun sampling didasarkan pada informasi keberadaan kepiting bakau yang didapatkan dari nelayan penangkap kepiting.

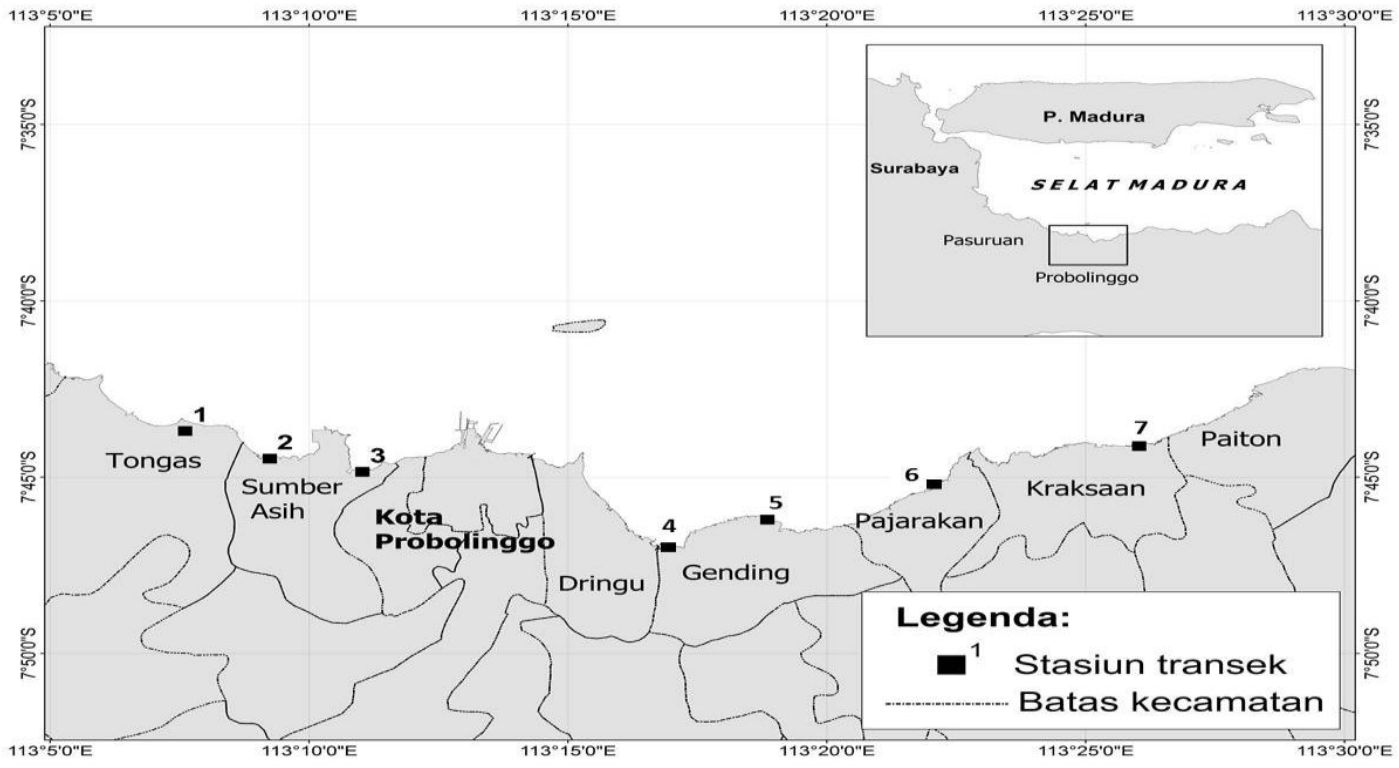

Gambar 1. Peta lokasi penelitian di areal pertambakan Probolinggo, Jawa Timur

\section{Profil Pesisir dalam Perspektif Keong Famili Potamididae}

Profil pesisir dibuat berdasar foto udara dan hasil observasi lapangan. Pengukuran beda tinggi antara titik-titik sasaran unsur-unsur morfologi pantai dilakukan berdasar metode geodetik dengan alat ukur sifat datar Sokhiza tipe B2C, rambu ukur, GPS, kompas, lensa pembesar dan tabel pasang-surut dari Pelabuhan Probolinggo. Penentuan posisi geografi lokasi pengukuran diukur dengan GPS GARMIN 76 XL berakurasi $10 \mathrm{~m}$. Pengolahan citra dalam penyusunan peta mempergunakan perangkat Arc GIS versi 10. 


\section{Pengukuran Parameter Lingkungan}

Pengukuran kecepatan dan arah arus, kedalaman perairan, suhu dan salinitasair menggunakan ADCP 1200 Khz, Salinity Sensor yang diintegrasikan pada Tide and Wave Gauge dan GPS Garmin 276C. Salinitas air diukur dengan termometer. Suhu air diukur dengan refraktometer. Arus dan kedalaman perairan diukur dengan Acoustic Doppler Current Profiler (ADCP).Profil vertikal arus diukur pada interval 25 $\mathrm{cm}$ dari permukaan hingga kedalaman 21 meter sepanjang lintasan perahu yang bergerak dengan kecepatan antara 4-5 knot. Penentuan posisi dilakukan dengan GPS Garmin 276 GPS dan Bottom Tracking dari ADCP.

\section{Metode Sampling Keong Potamididae}

Keong Potamididae yang diperoleh dari lokasi penelitian dengan metode Purposive Random Sampling. Koleksi dilakukan dengan meletakkan kerangka kuadrat berukuran $1 \mathrm{~m}^{2}$ di atas substrat di sekeliling tambak yang telah ditentukan sebelumnya. Banyaknya kerangka ditentukan berdasar hasil sampling awal dengan memperhatikan perubahan jumlah spesies yang diperoleh. Jika pada jumlah kuadrat tertentu sudah tidak terdapat penambahan jumlah spesies, maka jumlah kuadrat tersebut dijadikan acuan penentuan jumlah kerangka kuadrat masing-masing stasiun. Habitat alami dan perilaku saat masih di lapangan diabadikan dalam bentuk foto untuk masing-masing spesies dari Famili Potamididae tersebut. Semua individu yang diperoleh di lapangan diambil dan dimasukkan ke dalam botol sampel, dan kemudian difiksasi dengan menggunakan air tawar dan diawetkan dalam ethanol 96\% untuk kemudian dianalisa lebih lanjut di laboratorium.

Sampel diidentifikasi dan dianalisis terutama berdasarkan karakter morfologi dan anatominya. Spesimen yang diamati hanya spesimen dewasa, yaitu yang telah memiliki karakter cangkang yang lengkap dan mencapai pertumbuhan maksimum. Spesimen yang masih juvenil tidak diamati karakternya, tetapi jumlah individunya tetap dihitung. Data karakter diperoleh dari pengamatan morfologi, anatomi, perilaku, dan ekologi (Houbrick, 1988). Identifikasi pada tingkat genus dan spesies terutama merujuk pada Altena (1940), Houbrick (1991), Jutting (1956), Reid et al. (2008) dan Wilson (1993).

\section{HASIL DAN PEMBAHASAN}

\section{Kondisi Mangrove sebagai Habitat Keong Potamididae}

Kawasan Probolinggo terletak di kaki utara Gunung Bromo dengan morfologi dataran pesisir yang sangat sempit ( \pm 1-4 Km), tersusun oleh material pasir vulkanik. Dataran pesisir sebagian besar merupakan lahan pertambakan tradisional. Jenis mangrove yang ditemukan pada lokasi penelitian antara lain Rhizophora stylosa, R. mucronata, R. lamarckii, 
Soneratia alba, Xylocarpus granatum dan Avicennia marina. Rhizophora stylosa merupakan jenis yang paling dominan. Data hasil revisi peta menunjukkan bahwa wilayah pesisir sekitar 7,6 ribu hektar, dan $\pm 20 \%$ di antaranya (2,5 ribu hektar) berupa wilayah mangrove dan pertambakan yang tersebar di sepanjang pesisir Kabupaten dan Kota Probolinggo (Gambar 2).

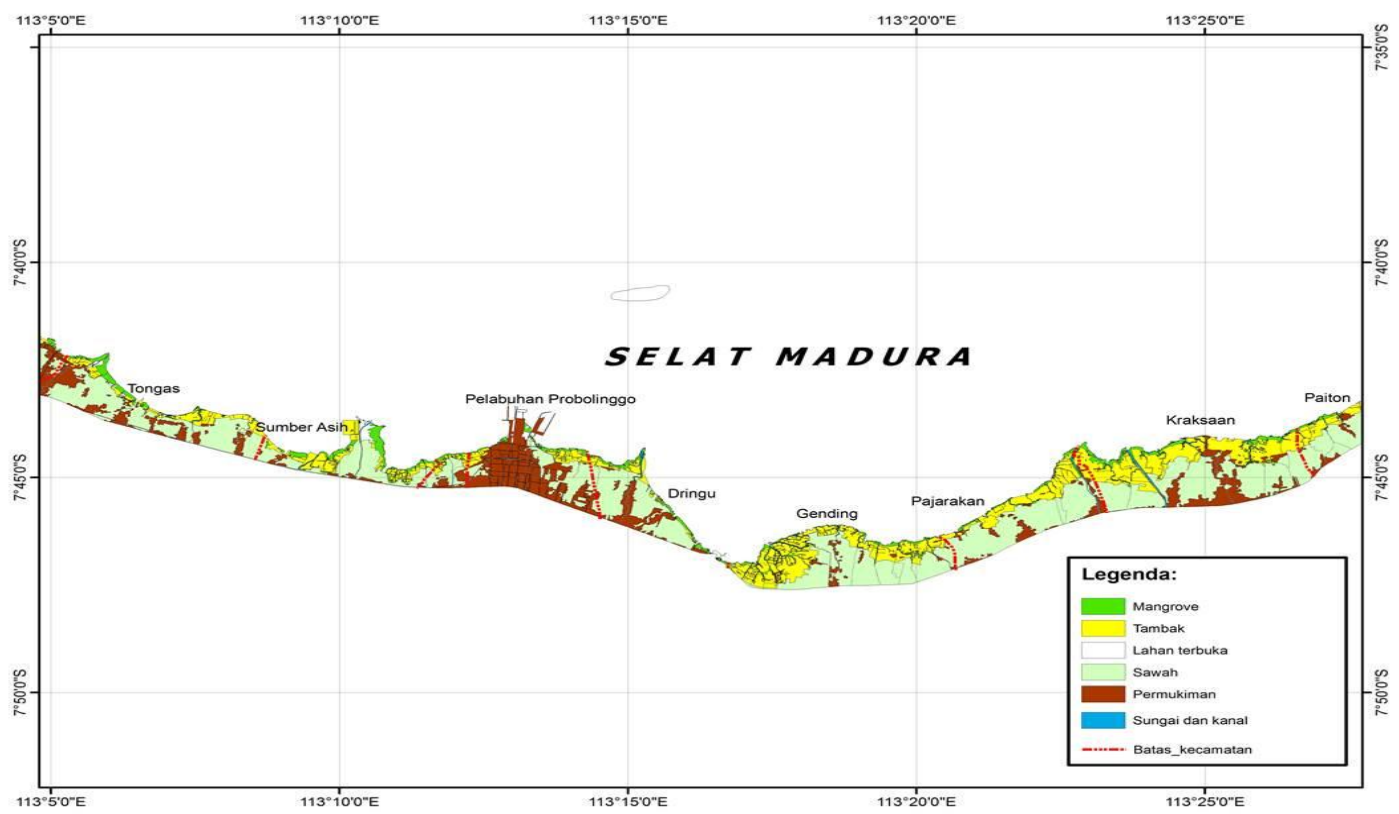

Gambar 2. Profil pesisir di wilayah Kabupaten dan Kota Probolinggo

Hasil pengukuran dan penggambaran profil topografi pantai kawasan pertambakan (Gambar 3) menunjukkan tinggi pematang/tanggul terdepan hampir sama dengan permukaan air laut saat pasang purnama, yakni 1,42 m di atas Muka Laut Rata-rata (MLR). Namun, tinggi pematang antar tambak lebih rendah, dan saat pasang bisa tergenang 5-10 cm. Para petambak setidaknya mempunyai satu kali pergantian air laut yang berlangsung selama kurang lebih 7 hari pada rentang waktu 14 hari.

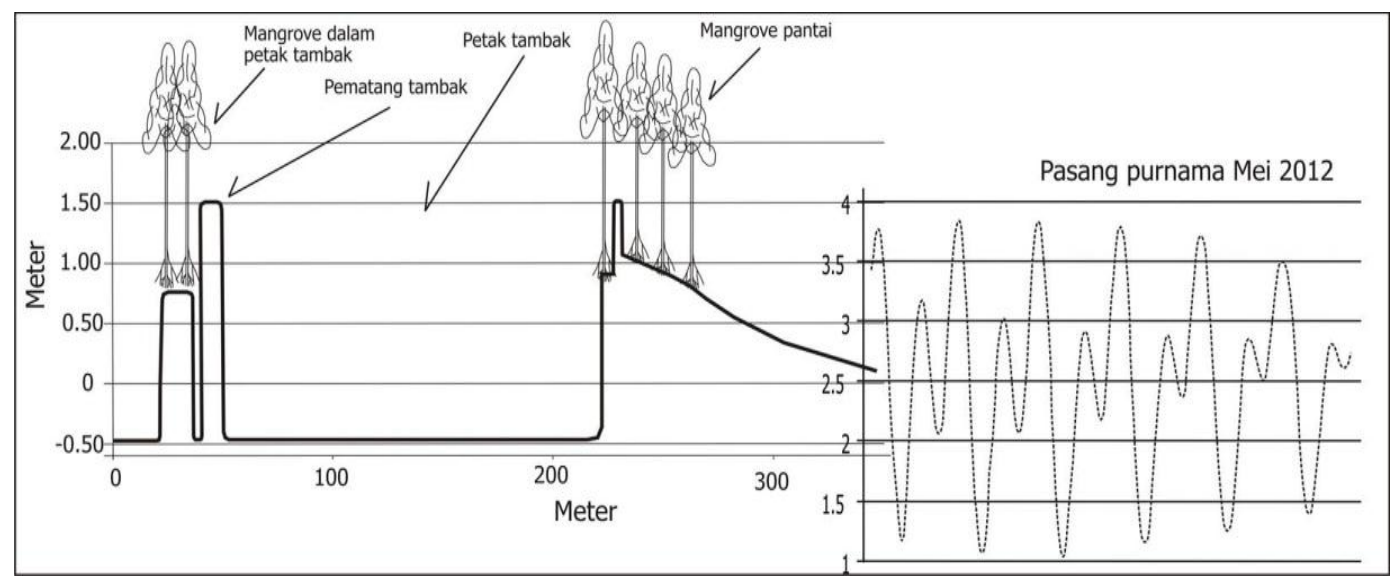

Gambar 3. Profil pantai di Probolinggo secara umum 
Gambaran mengenai kondisi beberapa parameter habitat yang diamati pada masing-masing stasiun penelitian disajikan pada Tabel 1.

Tabel 1. Deskripsi habitat pada masing-masing stasiun

\begin{tabular}{|c|c|c|c|c|}
\hline \multirow{2}{*}{$\begin{array}{l}\text { Sta- } \\
\text { siun }\end{array}$} & \multicolumn{4}{|c|}{ Karakter Habitat } \\
\hline & Keberadaan Mangrove & $\begin{array}{c}\text { Jenis } \\
\text { Substrat }\end{array}$ & $\begin{array}{l}\text { Jarak ke } \\
\text { Laut }\end{array}$ & $\begin{array}{l}\text { Kanal/ } \\
\text { Sungai }\end{array}$ \\
\hline 1 & $\begin{array}{l}\text { Tersebar acak di } \\
\text { sepanjang pematang } \\
\text { tambak }\end{array}$ & $\begin{array}{l}\text { Pasir } \\
\text { berlumpur }\end{array}$ & 200 meter & $\begin{array}{l}\text { Ada, } \\
\text { kanal } \\
\text { kecil }\end{array}$ \\
\hline 2 & $\begin{array}{l}\text { Tidak ada di sekitar } \\
\text { tambak, ada dengan jarak } \\
\text { sekitar } 200 \text { meter }\end{array}$ & $\begin{array}{l}\text { Pasir } \\
\text { berlumpur }\end{array}$ & 50 meter & $\begin{array}{l}\text { Ada, } \\
\text { kanal } \\
\text { kecil }\end{array}$ \\
\hline 3 & $\begin{array}{l}\text { Tersebar acak di } \\
\text { sepanjang pematang } \\
\text { tambak }\end{array}$ & $\begin{array}{l}\text { Lumpur } \\
\text { campur } \\
\text { pecahan } \\
\text { cangkang }\end{array}$ & 200 meter & $\begin{array}{l}\text { Ada, } \\
\text { kanal } \\
\text { agak } \\
\text { besar }\end{array}$ \\
\hline 4 & $\begin{array}{l}\text { Tersebar acak di } \\
\text { sepanjang pematang } \\
\text { tambak }\end{array}$ & Lumpur & 600 meter & $\begin{array}{l}\text { Ada, } \\
\text { kanal } \\
\text { kecil }\end{array}$ \\
\hline 5 & $\begin{array}{l}\text { Cukup lebat di bagian } \\
\text { tengah tambak }\end{array}$ & $\begin{array}{l}\text { Pasir } \\
\text { berlumpur }\end{array}$ & 300 meter & $\begin{array}{l}\text { Ada, } \\
\text { kanal } \\
\text { kecil }\end{array}$ \\
\hline 6 & $\begin{array}{l}\text { Hanya beberapa tegakan } \\
\text { di tepi sungai }\end{array}$ & Lumpur & 300 meter & $\begin{array}{l}\text { Ada, } \\
\text { sungai } \\
\text { kecil }\end{array}$ \\
\hline 7 & $\begin{array}{l}\text { Hanya beberapa tegakan } \\
\text { di sepanjang pematang } \\
\text { tambak }\end{array}$ & $\begin{array}{l}\text { Pasir } \\
\text { berlumpur }\end{array}$ & 200 meter & $\begin{array}{l}\text { Ada, } \\
\text { kanal } \\
\text { kecil }\end{array}$ \\
\hline
\end{tabular}

\section{Karakteristik Parameter Fisika}

Pasang surut yang diukur selama 6 hari, menjelang, saat dan setelah bulan purnama menghasilkan pola dengan kisaran 0-2,8412 m dan nilai duduk tengah $1,508 \mathrm{~m}$. Perairan Laut Jawa memiliki tinggi pasang surut umumnya berkisar antara 1-2 m Penyebab tingginya nilai maksimum pasang karena posisinya yang merupakan bagian dari teluk semi tertutup menghadap ke Selat Madura. Hasil pengukuran sesuai dengan yang dinyatakan Wyrtki (1961), yaitu tipe campuran yang didominasi ganda. Artinya, dalam sehari terjadi dua kali pasang, sekali pasang besar dan pasang berikutnya lebih kecil. Pematang tambak (tanggul) yang langsung menghadap ke laut umumnya lebih tinggi dari muka air laut saat pasang tinggi. Air laut saat pasang masuk area pertambakan melalui kanal-kanal buatan dan beberapa sungai kecil. Pematang antar tambak dibuat lebih rendah dari muka air laut saat pasang tinggi, sehingga air laut yang masuk ke kanal mampu melampaui pematang-pematang tambak. 
Hasil pengukuran salinitas air laut mulai dari permukaan hingga kedalaman $3 \mathrm{~m}$, salinitas berkisar 30,5-32 psu. Pada kedalaman $4 \mathrm{~m}$ hingga dekat dasar, salinitas yang tercatat berkisar antara 32-33 psu. Salinitas tertinggi di dekat dasar dengan nilai mencapai 33 psu.

Ketika pasang maksimum, suhu air di perairan pesisir mengalami penurunan akibat dari mengalirnya massa air dari laut lepas. Massa air di pesisir pada Pantai Probolinggo relatif dangkal mengalami pemanasan dari matahari sangat efektif, terutama ketika air mulai surut. Selain itu, tercatat trend penurunan suhu ketika amplitudo harian pasang surut mulai menurun seiring dengan kondisi bulan yang menuju ke bulan gelap. Profil suhu dengan kedalaman perairan 20 meter menunjukan bahwa suhu permukaan berada pada kisaran $29,5^{\circ} \mathrm{C}$ menurun mengikuti kedalaman perairan hingga mencapai $28,5-29^{\circ} \mathrm{C}$. Suhu air laut di pesisir naik ketika menuju surut yang terjadi pada siang hari. Suhu permukaan air laut yang terekam berkisar $29,06-31,44^{\circ} \mathrm{C}$ dengan rata-rata $30,37^{\circ} \mathrm{C}$. Perbedaan suhu permukaan antara maksimum dan minimum dalam pola pasang surut mencapai $2,38^{\circ} \mathrm{C}$, dan angka ini cukup besar untuk perairan Indonesia pada umumnya.

Kondisi aliran air permukaan di Perairan Probolinggo yang merupakan bagian dari perairan yang berbentuk teluk dengan kedalaman perairan mulai dari pantai, 0-30 m sangat dipengaruhi oleh pasang surut, topografi dan kondisi angin. Pada saat pasang, air laut masuk ke perairan melalui mulut teluk disebelah timur perairan menuju ke Perairan Probolinggo kemudian karena perairan di selatan Pulau Gili dangkal, massa air membelok keselatan kemudian menyusur pantai ke arah imur. Sedangkan saat surut, masa air yang berasal dari pesisir keluar dari Perairan Probolinggo melaui pesisir mengalir ke timur. Berdasarkan data pengukuran arus selama 6 hari, diperoleh bahwa aliran massa air selalu mengarah ke timur, baik saat pasang maupun saat surut. Pola arus di Perairan Probolinggo di atas memungkinkan untuk mengantar larva biota settling di Pesisir Probolinggo. Hal ini sangat menguntungkan, dan menjadi salah satu faktor yang mempertahankan populasi biota untuk tetap berada di sepanjang wilayah Kabupaten dan Kota Probolinggo.

\section{Komposisi Spesies}

Hasil pengamatan, menunjukkan bahwa keong Famili Potamididae meliputi seluruh wilayah pesisir Probolinggo. Sebanyak 1229 individu keong dari delapan spesies yang termasuk dalam tiga genus (Telescopium, Cerithidea dan Cerithideopsilla) dari Famili Potamididae berhasil diidentifikasi (Gambar 4). Komposisi spesies keong Famili Potamididae yang didapatkan di lokasi penelitian disajikan pada Tabel 2. Dari Tabel 2 diketahui jumlah spesies terbanyak terdapat pada Stasiun 3 (6 spesies), dan jumlah spesies paling sedikit terdapat pada Stasiun 1 dan Stasiun 7 (masing-masing 2 spesies). 


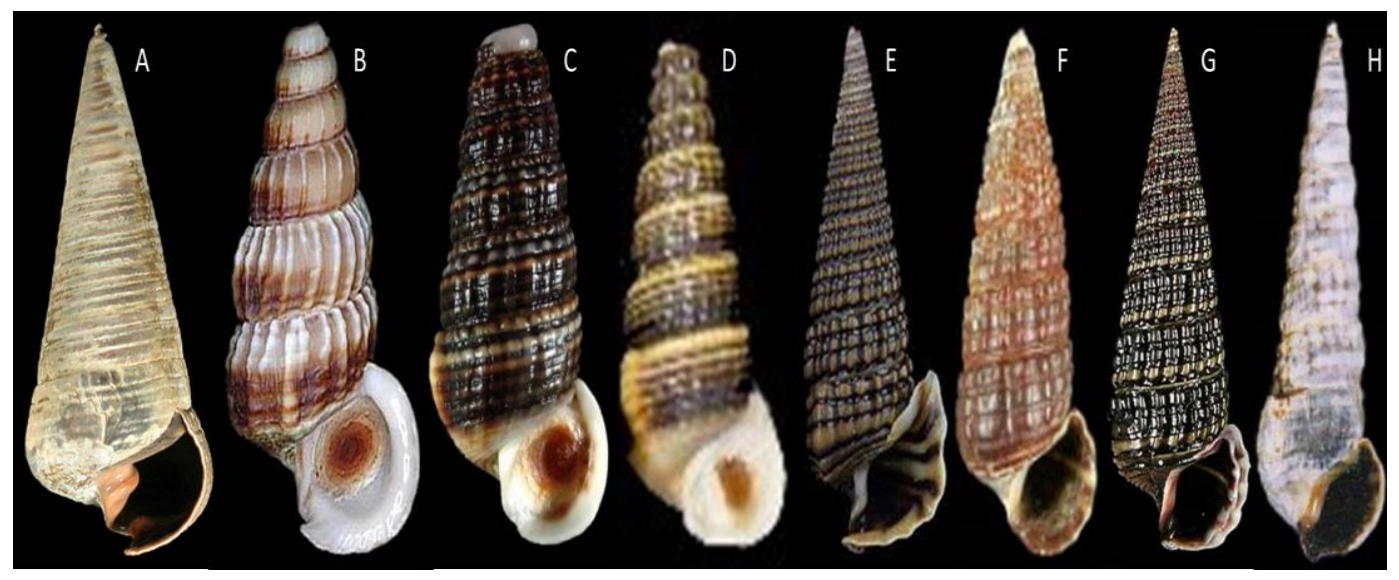

Gambar 4. Jenis-jenis keong Famili Potamididae yang ditemukan di lokasi penelitian: A) Telescopium telescopium, B) Cerithidea obtusa, C) Cerithidea rhizophorarum, D) Cerithidea weyersi, E) Cerithidea microptera, F) Cerithideopsilla alata, G) Cerithideopsilla cingulata, H) Cerithideopsilla djadjariensis

Tabel 2. Komposisi spesies keong Famili Potamididae di lokasi penelitian

\begin{tabular}{|c|c|c|c|c|c|c|c|c|}
\hline \multirow{2}{*}{ No } & \multirow{2}{*}{$\begin{array}{l}\text { Jenis Keong } \\
\text { Potamididae }\end{array}$} & \multicolumn{7}{|c|}{ Stasiun } \\
\hline & & 1 & 2 & 3 & 4 & 5 & 6 & 7 \\
\hline 1 & $\begin{array}{l}\text { Telescopium } \\
\text { telescopium }\end{array}$ & - & + & + & + & + & + & - \\
\hline 2 & $\begin{array}{l}\text { Cerithidea } \\
\text { rhizophorarum }\end{array}$ & + & - & - & + & - & + & - \\
\hline 3 & $\begin{array}{l}\text { Cerithidea } \\
\text { weyersi }\end{array}$ & - & + & + & - & - & + & - \\
\hline 4 & $\begin{array}{l}\text { Cerithidea } \\
\text { obtuse }\end{array}$ & - & - & + & - & - & - & - \\
\hline 5 & $\begin{array}{l}\text { Cerithidea } \\
\text { microptera }\end{array}$ & - & - & + & - & - & - & - \\
\hline 6 & $\begin{array}{l}\text { Cerithideopsilla } \\
\text { alata }\end{array}$ & - & - & + & + & - & - & - \\
\hline 7 & $\begin{array}{l}\text { Cerithideopsilla } \\
\text { cingulata }\end{array}$ & + & + & + & - & + & + & + \\
\hline 8 & $\begin{array}{l}\text { Cerithideopsilla } \\
\text { djadjariensis }\end{array}$ & - & - & - & + & - & - & + \\
\hline
\end{tabular}

Dilihat dari komposisi spesies pada masing-masing stasiun, terlihat bahwa pada beberapa stasiun hanya terdapat dua atau tiga spesies dengan salah satu spesies sangat dominan (pada Stasiun 1, Stasiun 2, Stasiun 5 dan Stasiun 7). Sedangkan pada stasiun lainnya komposisi spesiesnya terlihat lebih bervariasi dengan jumlah individu masing-masing spesies lebih berimbang (Gambar 5). 


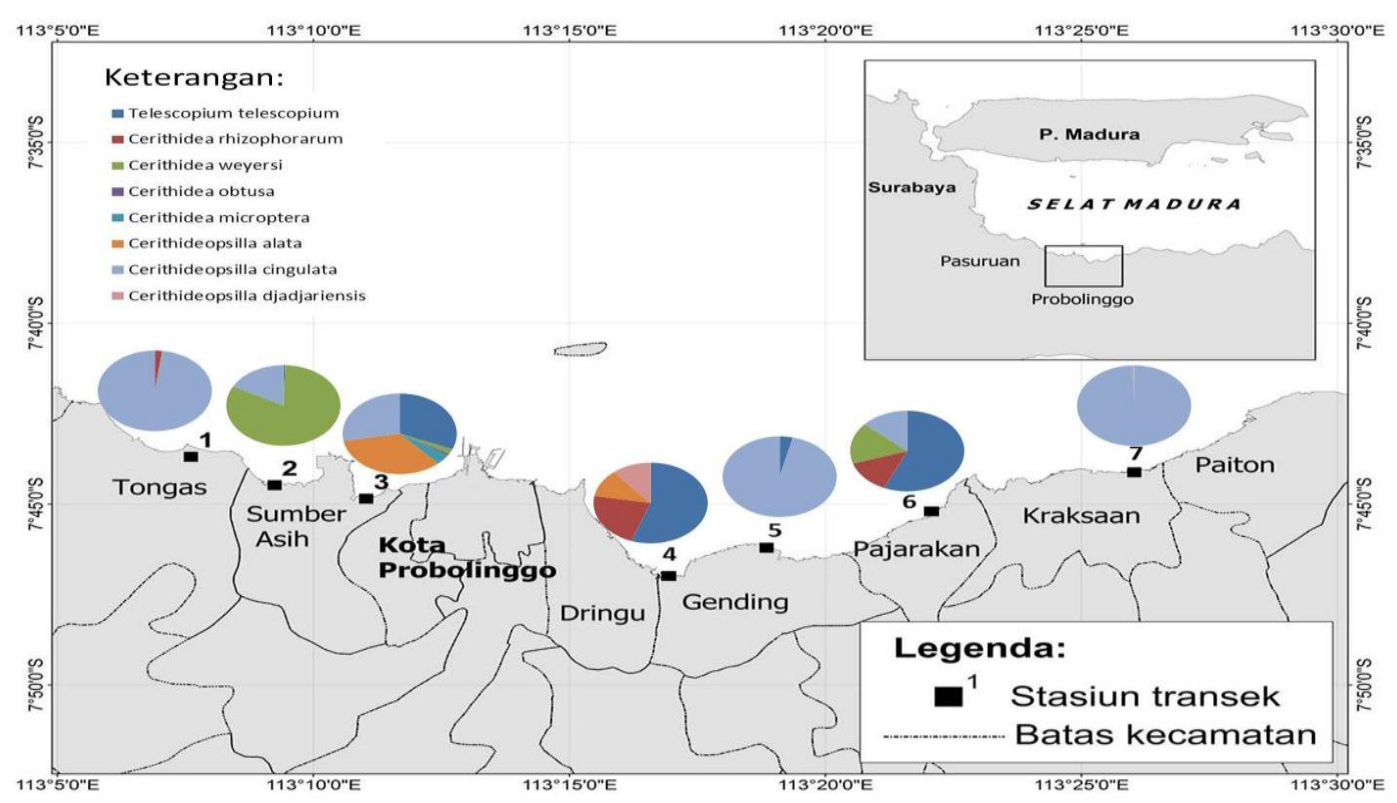

Gambar 5. Komposisi spesies tiap stasiun pada lokasi penelitian

Sedikitnya jumlah spesies dan adanya dominasi spesies yang terjadi pada stasiun 1, stasiun 2, stasiun 5 dan stasiun 7 diduga tidak terlepas dari pengaruh yang kuat dari kondisi substrat pada masingmasing stasiun tersebut. Pada keempat stasiun tersebut memiliki substrat pasir berlumpur, terutama pada stasiun 2 yang substratnya cenderung berupa pasir. Pada habitat seperti ini, mangrove umumnya memiliki tingkat pertumbuhan yang kurang optimal. Akibatnya adalah ketersediaan pakan bagi keong Famili Potamididae menjadi terbatas. Pada Stasiun 2 bahkan sama sekali tidak terdapat vegetasi mangrove di sekitar tambak, sedangkan jarak dengan mangrove terdekat sekitar 200 meter. Kondisi ini semakin menjadikan sebagian besar keong Famili Potamididae berada jauh di luar zona kondisi habitat optimal, terutama dalam hal ketersediaan pakan (Budiman, 1991). Kondisi yang berbeda terlihat pada stasiun 3, stasiun 4 dan stasiun 6 dimana tidak ada dominasi dari spesies tertentu. Spesies-spesies yang didapatkan terdiri dari jenis-jenis yang memiliki kecenderungan untuk memilih habitat dengan substrat berlumpur. Sebagai contoh adalah Telescopium telescopium yang diketahui memiliki kebiasaan menguburkan sebagian atau seluruh tubuhnya ke dalam substrat berlumpur (Budiman, 1991). Keberadaan mangrove yang cukup banyak di ketiga stasiun tersebut juga menjadi faktor penting bagi kehidupan berbagai jenis keong Famili Potamididae.

Dilihat dari jumlah individu tiap spesies, Cerithideopsilla cingulata merupakan jenis yang paling dominan ditemukan $(60,94 \%)$, yang diikuti dengan Cerithidea weyersi $(25,63 \%)$ dan Telescopium telescopium (7,73\%) (Gambar 6A). Cerithideopsilla cingulata ditemukan dalam agregasi yang sangat besar hampir di semua stasiun, kecuali di Stasiun 4. Dilihat dari jumlah individu tiap stasiun, terlihat bahwa Stasiun 2 dan Stasiun 7 memiliki jumlah individu yang berimbang, yaitu sebanyak $29,86 \%$ dan $29,29 \%$ dari total individu yang didapatkan (Gambar 6B). 
Namun demikian, pada Stasiun 7 walaupun memiliki jumlah individu yang termasuk paling banyak namun memiliki jumlah spesies yang paling sedikit. Artinya bahwa pada stasiun tersebut terdapat dominasi oleh jenis tertentu.
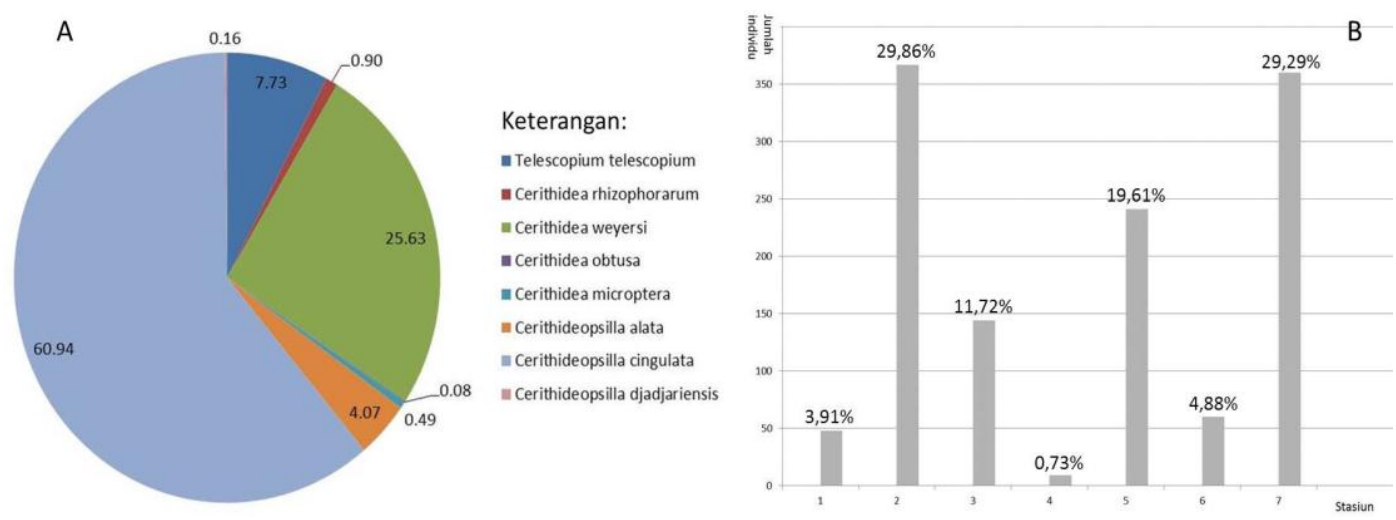

Gambar 6. Prosentasi individu keong Famili Potamididae di lokasi penelitian: A) Jumlah individu tiap spesies; B) Jumlah individu tiap stasiun

Keberadaan tiga spesies yaitu Cerithideopsilla cingulata, Cerithidea weyersi dan Telescopium telescopium yang mendominasi di lokasi penelitian diduga karena kawasan pertambakan Probolinggo merupakan habitat yang cocok bagi ketiga spesies tersebut. Makanan yang melimpah sangat menentukan suatu spesies untuk bertahan pada suatu lokasi. Selain menyediakan makanan dan tempat hidup yang memadai, kondisi fisik habitat juga mendukung perkembangan populasi (Budiman, 1991). Waktu sampling juga dapat dijadikan alasan tentang hasil penelitian tersebut. Berdasarkan penelitian Vohra (1970), Cerithideopsilla cingulata beberapa spesies dalam Famili Potamididae ditemukan dalam fase pemijahan ketika musim hujan. Penelitian di Probolinggo ini dilakukan pada akhir musim penghujan. Hasilnya, spesimen Cerithideopsilla cingulata yang ditemukan dalam penelitian ini sebagian besar di antaranya merupakan individu yang masih juvenil dan remaja. Jenis substrat yang pada umumnya berupa lumpur sangat mendukung jenis Telescopium telescopiumuntuk hidup. Menurut Budiman (1991), jenis ini memiliki kebiasaan memakan serasah daun dan batang mangrove yang telah membusuk pada substrat berlumpur.

Jika dibandingkan, komposisi spesies Gastropoda antara ekosistem mangrove areal pertambakan, akan berbeda dengan ekosistem mangrove di pulau-pulau kecil, walaupun sama-sama merupakan ekosistem yang mengalami degradasi secara fisik. Hal ini berkaitan dengan perbedaan tingkat kemampuan masing-masing jenis Gastropoda untuk beradaptasi terhadap faktor lingkungan. Perbedaan variasi faktor lingkungan juga menyebabkan perbedaan strategi hidup dan penyebaran Gastropoda.Berdasar strategi hidupnya terhadap substrat, Gastropoda di ekosistem mangrove dapat hidup sebagai epifauna (di permukaan substrat), infauna (di dalam substrat), maupun treefauna (pada akar, batang dan daun mangrove). Sedangkan berdasarkan cara 
penyebarannya, Gastropoda di ekosistem mangrove dapat menyebar secara vertikal maupun horizontal terhadap garis pantai. Pengelompokan tersebut berkaitan erat dengan strategi adaptasi terhadap perubahan lingkungan yang disebabkan oleh pengaruh pasang surut yang terjadi di ekosistem mangrove (Sasekumar, 1974; Budiman, 1991).

Seleksi habitat oleh suatu organisme berkontribusi untuk kelanjutan/kelestarian generasi berikutnya (Webley et al., 2009). Layman et al. (2006) mendefinisikan nursery habitat sebagai tempat yang memungkinkan kelulusan hidup juvenil yang tinggi (menyediakan pakan dan perlindungan), yang sangat berperan untuk generasi yang akan datang. Namun demikian, nursery ground mungkin bukan penyumbang terbesar bagi kelangsungan hewan dewasa (Dahlgren et al., 2006). Artinya, daerah yang dipilih untuk perkembangan larva dan juvenile bisa saja berbeda dengan daerah yang dipilih oleh hewan ketika dewasa.

Dilihat dari hasil dari penelitian ini, keong Famili Potamididae di pesisir Probolinggo potensial untuk mendukung pembesaran dan budidaya kepiting bakau. Menurut Sara et al. (2007), moluska (termasuk Gastropoda) merupakan pakan alami yang sangat penting bagi kepiting bakau. Hasil analisa isi perut menunjukkan bahwa selain bagian lunak moluska, cangkang juga merupakan pakan penting bagi kepiting bakau, yaitu sebagai sumber utama untuk pertumbuhan karapas kepiting. Secara alami kepiting bakau akan sulit memangsa keong Famili Potamididae karena cangkangnya yang relatif keras, sehingga kepiting bakau akan memilih kelompok moluska lain yang memiliki cangkang yang lebih lunak. Berdasarkan pengamatan di Likupang, Sulawesi Utara, sebagian besar pakan untuk pembesaran kepiting bakau adalah berupa keong Famili Potamididae. Jenis-jenis yang dimanfaatkan adalah yang berukuran besar dan melimpah, misalnya Telescopium telescopium dan Terebralia palustris.

Tiap organisme memerlukan kombinasi faktor lingkungan optimum agar dapat tumbuh dan berkembang biak dengan baik. Menurut Hutabarat \& Evans (1985), Gastropoda memiliki kondisi habitat optimum pada suhu $25-32^{\circ} \mathrm{C}$ dan salinitas $25-40 \%$. Kondisi lingkungan menentukan pola sebaran dan sekaligus membatasi sebaran organisme (Budiman, 1991). Semakin jauh lokasi dari pusat kondisi optimum, maka aktivitas biologinya kian menurun, sampai pada suatu tempat yang tidak lagi mendukung kehidupan jenis tersebut. Budiman (1991) menyatakan bahwa pengertian dan konsep hubungan antar organisme dan kondisi lingkungan dapat dipakai untuk menjelaskan adanya pengelompokan dan pola sebaran.

Gastropoda yang berasosiasi dengan mangrove memiliki kemampuan adaptasi yang tinggi terhadap perubahan lingkungan (Egonmwan, 2008). Kelompok Gastropoda tersebut memiliki kemampuan hidup di dalam dan di permukaan air, memiliki kemampuan dalam memanfaatkan bahan organik dengan baik, memiliki pola reproduksi yang dipengaruhi pasang surut. Pasang surut dan kehadiran mangrove merupakan dua faktor lingkungan yang sangat mempengaruhi kehadiran dan sebaran jenis moluska mangrove (Nagelkerken et al., 2008). Kombinasi dua faktor tersebut menyebabkan spesifikasi berbagai faktor 
lingkungan lain seperti suhu, kelembaban, naungan, ketersediaan pakan, pembentukan tekstur substrat, durasi ketergenangan dan lainnya. Variasi kombinasi kedua faktor tersebut juga mengakibatkan variasi biota yang berasosiasi di dalamnya. Menurut Budiman (1991), Famili Potamididae kurang dipengaruhi oleh kelembaban, namun beberapa di antaranya sangat tergantung pada naungan dan frekuensi penggenangan. Sampai tingkat tertentu, perbedaan toleransi terhadap naungan dan kondisi yang diakibatkan (misalnya fluktuasi suhu/air/tanah dan kelembaban) dapat dipakai untuk memisahkan Famili Potamididae menjadi dua kelompok, yaitu kelompok yang memiliki toleransi tinggi (Genus Telescopium, Cerithideopsilla, Cerithideopsis dan Cerithidea), dan kelompok yang kurang dapat bertoleransi (Genus Terebralia).

\section{KESIMPULAN}

Hasil penelitian keong Famili Potamididae di pertambakan Probolinggo ditemukan delapan spesies yang terdiri dari tiga genus. Area mangrove yang terdegradasi menjadi pertambakan masih memenuhi syarat sebagai tempat hidup keong Famili Potamididae. Kondisi substrat dan keberadaan mangrove berperan dalam menentukan komposisi spesies. Salinitas dan suhu dari air yang masuk ke kawasan pertambakan memunginkan larva berkembang, ditunjang dengan pasang yang relatif tinggi yang memungkinkan air laut masuk ke wilayah pertambakan ikut mendorong terbawanya settled larvae. Pola sebaran salinitas air laut dan kedalaman laut menjamin kelangsungan migrasi yang cukup dekat. Pola arus di Selat Madura berperan membawa larva kembali ke pesisir Probolinggo.

\section{UCAPAN TERIMA KASIH}

Ucapan terima kasih penulis sampaikan kepada Bapak Suyarso dari Pusat Penelitian Oseanografi LIPI selaku koordinator kegiatan penelitian di areal pertambakan Probolinggo ini. Penulis juga menyampaikan terima kasih kepada lbu Pradina Purwati dari Pusat Penelitian Oseanografi LIPI atas masukan-masukannya selama kegiatan di lapangan dan selama analisis data di laboratorium.

\section{DAFTAR PUSTAKA}

Altena, C.O.R. van. 1940. A revision of Cerithidea (Cerithideopsilla) cingulata (Gmelin) and some related species (Mollusca, Gastropoda). Zoologische Mededeelingen 22: 211-222.

Budiman, A. 1991.Penelaahan beberapa gatra ekologi moluska bakau Indonesia. Disertasi Fakultas Pasca Sarjana Universitas Indonesia, Depok: 380 hal. 
Dahlgren, C.P., G.T. Kellison, A.J. Adams, B.M. Gillanders, M.S. Kendall, C.A. Layman, J.A. Ley, I. Nagelkerken and J.E. Serafy. 2006. Marine nurseies and effective juvenile habitats: Concepts and applications. Marine Ecology Proggress Series 312 : 291-295.

Egonmwan, R.I. 2008. The ecology and habitat of Tympanotonus fuscatus var. radula L. (Cerithiacea: Potamididae). Journal of Biological Sciences 8(1): 186-190.

Houbrick, R.S. 1988. Cerithioidean phylogeny.Malacological Review Suppl. 4: 88-128.

Houbrick, R.S. 1991. Systematic review and functional morphology of the mangrove snails Terebralia and Telescopium (Potamididae; Prosobranchia).Malacologia 33(1-2): 289-338.

Hutabarat, S. dan S.M. Evans. 1985. Pengantar Oseanografi. Penerbit Universitas Indonesia, Jakarta: 159 hal.

Jutting, W.S.S.J. 1956. Systematic studies on the non-marine Mollusca of the Indo-Australian Archipelago. V. Critical revision of freshwater gastropods. Treubia 23(2): 259-477.

Layman, C.A., C.P. Dahlgren, G.T. Kellison, A.J. Adams, B.M. Gillanders, M.S. Kendall, J.A. Ley, I. Nagelkerken and J.E.Serafy. 2006. Marine nurseries and effective juvenile habitats. Marine Ecology Proggress Series 318: 307-308.

Nagelkerken, I., S.J.M. Blaber, S. Bouillon, P. Green, M. Haywood, L.G. Kirton, J.O. Mainecke, J. Pawlik, H.M. Penrose, A. Sasekumar and P.J. Somerfield. 2008. The habitat function of mangroves for terrestrial and marine fauna: A review. Aquatic Botany 89: 155-185.

Reid, D.G., P. Dyal, P. Lozouet, M. Glaubrecht and S.T. Williams. 2008. Mudwhelks and mangroves: The evolutionary history of an ecological association (Gastropoda: Potamididae). Molecular Phylogenetics and Evolution 47: 680-699.

Sara, L., R.O. Aguilar, L.V. Laureta, R.B. Baldevarona and J.A. Ingles. 2007. The natural diet of the mud crabs (Scylla serrata) in Lawele Bay, Southeast Sulawesi, Indonesia. The Philippine Agricultural Scientist 90(1): 6-14.

Sasekumar, A. 1974.Distribution of macrofauna on Malayan mangrove shore.Journal of Animal Ecology 43(1): 51-69. 
Sukardjo, S. 2009. Mangroves for national development and conservation in Indonesia: Challenges for the future. Marine Reseach in Indonesia 34(1): 47-61.

Vohra, F.C. 1970. Some studies on Cerilhidea cingulata (Gmelin, 1791) on a Singapore sandy shore. Proceedings of the Malacological Society of London 39(2-3): 187-201.

Webley, J.A.C., R.M. Connolly and R.A. Young. 2009. Habitat selectivity of megalopae and juvenile mud crabs (Scylla serrata): Implications for recruitment mechanism. Mar. Biol. 156: 891-899.

Wells, F.E. and C.M. Lalli. 2003. Aspects of the ecology of the mudwhelks Terebralia palustris and T. semistriata in northwestern Australia. In: Wells, F.E., D.I. Walker and D.S. Jones (eds.) 2003. The Marine Flora and Fauna of Dampier, Western Australia. Western Australian Museum, Perth: 193-208.

Wilson, B. 1993.Australian Marine Shells. Odysey Publishing, Australia: $408 \mathrm{pp}$.

Wyrtki, K. 1961. Physical Oceanography of the Southeast Asean Water. Naga Report Vol II. California: The University of California, Scrips Institution of Oceanography. La Jolla. 195p. 